\title{
Model of Sustainable Tourism Village Development in Bali (Case Study: OMunity Bali in Sudaji Village, Sawan Sub-district, Buleleng District)
}

\section{Putu Surya Triana Dewi}

Interior Design Lecturer of Sekolah Tinggi Desain Bali, Indonesia

\section{Abstract}

The development of rural tourism is often directed to the concept of greedy tourism, to bring in the number of tourists as much as possible, so that further away from the aspect of sustainability of tourism itself. OMunity Bali, in Sudaji Village, as the case study, a community which promotes Sudaji Village by elevating the concept of ecologically-based spiritual tourism village. The purpose of this research is to conceptualize framework in the development of Sustainable Tourism Village by learning from Community in Sudaji Village so that it can be adopted by other tourism

Corresponding Author: Putu Surya Triana Dewi

Received: 24 May 2019 Accepted: 25 July 2019 Published: 4 August 2019 Publishing services provided by Knowledge E

(c) Putu Surya Triana Dewi. This article is distributed under the terms of the

Attribution License, which permits unrestricted use and redistribution provided that the original author and source are credited.

Selection and Peer-review under the responsibility of the ISTEcS 2019 Conference Committee.

\section{G OPEN ACCESS} villages through the descriptive method. The results of the study found that Tri Hita Karana should be the basis for the development of sustainable tourism villages in Bali by using the concept of 'village builds' - village as a subject; looking inside, exploring the local potential and local wisdom while minimizing outside influences.

Keywords: sustainable tourism village, local wisdom, Tri Hita Karana, OMunity, Bali.

\section{Introduction}

Tourism Village is growing in Bali, in line with the mission of the World Tourism Organization (WTO). In addition to attracting more tourists, the development of tourism villages also provides an impact of equitable distribution to the village level and raises the level of the community's economy. The WTO implies three principles for sustainable tourism: ecological sustainability, socio-cultural survival, and economic sustainability. According to Nuryanti (1993), a tourism village is a form of integration between attractions, accommodation, and supporting facilities presented in a community life structure that blends with the prevailing rules and traditions. In addition, according to Putra and Pitana (2010), the development of tourism village aims to involve the community in the development of tourism so they would not only be the object of tourism; the community must be 
aware and improve themselves by using tourism as a good tool for improving welfare as well preservation of cultural values as well as local customs.

In 2018 Bali had 104 tourism villages, each with different potential and uniqueness. Although pocketing the amount of which is quite a lot, still needed the right formula for the development of each of these tourism villages. This tourism village is susceptible to rubbing against business interests, so it is possible that deviation from vision and mission in the beginning. There are still many tourism activities in rural areas that tend to exploit existing resources. The purpose of building a tourism village is then no longer for the welfare of the community and the preservation of the village environment but only to pursue the number of tourist visits. As a result, many rural tourism attractions are damaged by the forms of mass tourism; it will damage the long-term rural resources. According to Simanungkalit, et al. (2017), rural development has always adhered to the concept of 'build the village' and not 'village builds.' In the concept of 'build the village' - village as an object, external factors play a role in determining the direction of village development, and this leads to the village increasingly dependent on external assistance.

In contrast, in the concept of 'village builds' - village as a subject, the role of the community becomes the main factor in building a resilient village. In the context of tourism, the magnitude of the role of outsiders often leads not to the needs of the village community. The development of rural tourism is often directed to the concept of greedy tourism to bring in the number of tourists as much as possible. Conversely, community-based development will lead to the form of sustainable tourism as it relates to the long-term interests of the community itself.

Sustainable Tourism Village is a concept that can answer the problem. The concept of Sustainable Tourism Village also leads to efforts to optimize existing development resources. During this time the village as a living entity is often treated as an object of development. As a result, many overlapping activities are not strengthening but weaken the village. For that reason, the concept and strategy of local wisdom are needed as the foundation of the development of this sustainable tourism village, to be a clear corridor when executed, and as an easy guideline to be adopted by the tourism villages in Bali.

OMunity Bali, in Sudaji Village, became the case study in this research. OMunity is a community that wants to promote Sudaji Village by elevating the concept of ecologicallybased spiritual tourism village. Moving from a village with no traditional backdrop, passing on local wisdom like traditional Balinese villages, OMunity seeks to unearth the meaning and history of Sudaji Village, returning its eroded Balinese values. Collaborate on the concept of Tri Hita Karana and sustainable tourism outlined by the World Tourism 
Organization (WTO) with emphasis on the sustainability of nature, socio-culture, and social economy; OMunity appears with its character. Hopefully in the future, this model of sustainable tourism village developed by OMunity could inspire another village in Bali how to turn a village with less potential resources to be sustainable tourism village; certainly based on local wisdom to bridge the gap between environmental issues and human interests through practical education and sustainable community involvement.

\section{Local Wisdom as a Sustainable Tourism Village Devel- opment Strategy Framework in Bali}

The study of local wisdom is an effort to create harmony and sustainable environment through the utilization of indigenous knowledge, contextual approach, and participatory approach. Local wisdom is a positive human behavior in dealing with nature and the surrounding environment, which can be sourced from religion, customs, ancestral wisdom, or local culture, which naturally builds in a community to adapt to the surrounding environment. Local wisdom arises through a long and lasting internalization process as a result of interaction between humans and their environment. This long evolutionary process leads to the emergence of a value system that is crystallized in the form of customary law, belief, and local culture (Wikantiyoso, 2009). The diversity of regional character, in addition to cultural aspects, contains local wisdom that can be a tourist attraction, and potentially increase the creative economic growth of the community. The potential of cultural assets has historical value, and becomes a series of heritage that needs to be preserved and even potential to be developed in a positive, sustainable and can be a foothold in the planning and design of a sustainable built environment.

One of the local wisdom that became the cultural insight of the Balinese is the philosophy of Tri Hita Karana. This philosophy became the basis of harmonious interaction pattern between the human being and environment, i.e., spiritual, social and physical environment. The harmonious and balanced relationship is convinced to bring benefit to the prosperity of human life both physically and spiritually (Sendra, 2011).

\section{Research Methods}

This sustainable village tourism study was conducted by observing directly the local village conditions and interviews with local communities using descriptive methods. To get the concept of sustainable tourism village in OMunity, Sudaji Village is using the descriptive method of analysis with identification and analysis based on aspects 
of local wisdom through the concept that has been presented by Wikantiyoso (2009) and Sendra (2011). This will be a parameter in assessing the development of Sudaj Village as spiritual eco-tourism village. The aspect used as a sustainable environmental parameter in OMunity in Sudaji Village leads to the Tri Hita Karana philosophy which became the local insight which became the foothold in the development of tourism village in Bali:

1. Aspects Parahyangan (harmonization of a man with the creator)

2. Aspects of Pawongan (harmonization of human beings with each other)

3. Aspects Palemahan (harmonization of a man with the environment)

The selection of these parameters is taken based on tangible elements because this research is qualitative.

\section{Results and Discussion}

\subsection{OMunity Bali}

OMunity is a community that wants to promote Sudaji Village by elevating the concept of ecologically-based spiritual tourism village. Sudaji Village located in Sawan District, Buleleng Regency, Bali Province. Topographically, Sudaji Village is a highland and mountains located at an altitude of 200 to 400 meters above sea level with $0-10 \%$ of the slope which causes Sudaji Village has cool weather. One of the tourism potentials owned by Sudaji Village is a tracking path that leads to Sekumpul waterfall. Beautiful landscapes such as rice fields managed by subak, rivers, and forests are the main attraction for tourists.

OMunity in its tourism activity, provides tourism accommodation of a kind of small retreat villa called OM Stay located in Sudaji Village, Singaraja, Bali. OMunity was founded in 2010 by Zanzan, on the background of Zanzan's concern for the local community's unfriendly of the environment and the presence of waste. Development that occurs even tends to damage the environment. It underlies his thinking to build an eco-friendly tourism concept and elevate the values of local wisdom. OMunity mission is to provide a sustainable future for posterity: a world without plastic, dangerous chemicals, and toxic fertilizers, where humans and nature thrive in symbiosis, the way nature intended. 
"We are going back to the basics - what our ancestors understood and practiced an environment where tourism entails being curious about a new culture and discovering its roots. Through food, culture, language, and way of living, tourist can get to know a new culture without destroying Bali's greatest asset: Mother Nature. We seek to educate and facilitate a cultural exchange between locals and visitors and to bridge the gap between environmental concerns and human interests through practical education and the involvement of Sudaji's community. The concept for OMunity is living with and among the community and local people of Sudaji, not against them or to nature's detriment." (Zanzan, 2018).

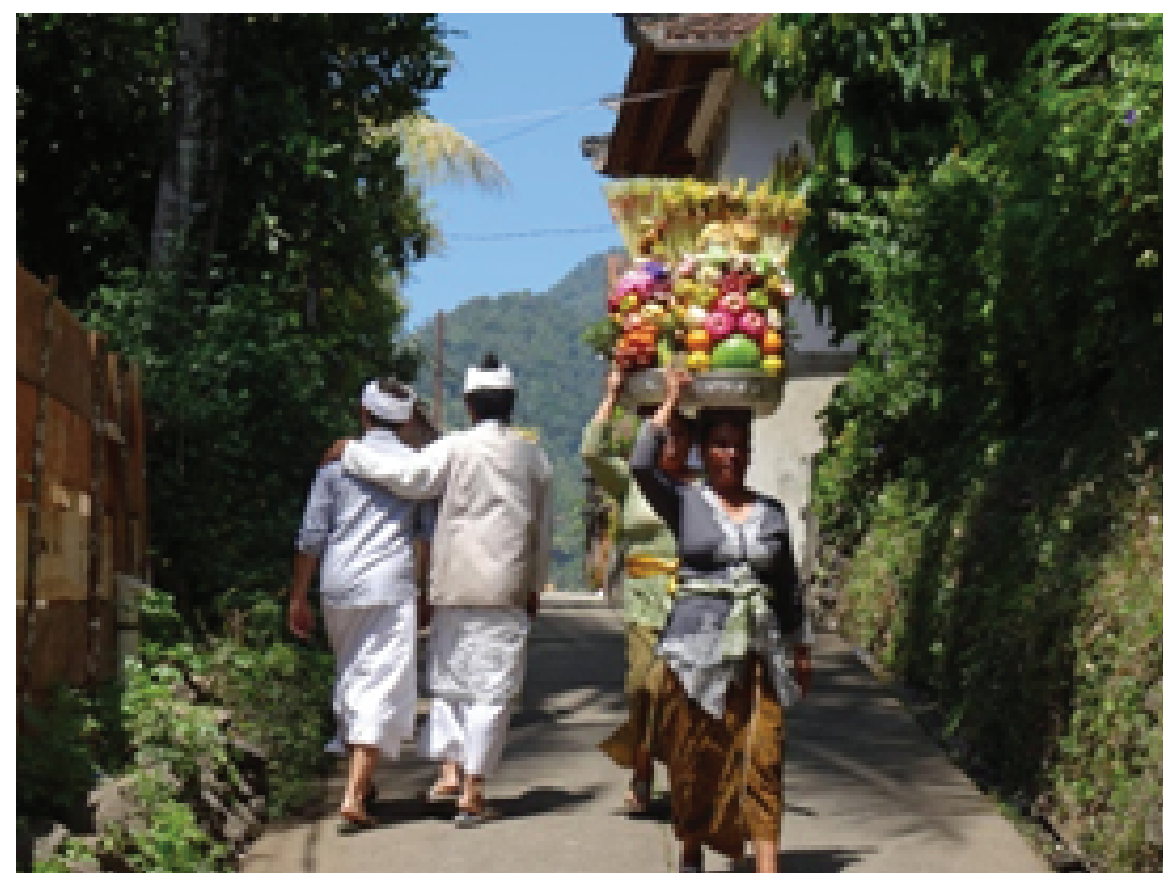

Figure 1: Balinese life in Sudaji.

The selection of Sudaji Village is based on Zanzan's vision to change the image of Sudaji Village, which initially has problems with the presence of garbage, has no specific tourism attractions such as culture or nature, then turned into ecologically-based spiritual tourism village. When viewed from the name 'Sudaj' itself derived from the word Suda and Aji (Sudaji) which Suda means clean, and Aji means teaching, indicating that ancestors of the people of Sudaji are already aware of the importance of environmental hygiene. The name OMunity itself originated from the word 'Community' derived from the theory of Community Based Tourism, the theory that became the framework that OMunity will grow from the participative community. Then Zanzan develops a foundation for OMunity's vision of 'vitamin C' from (C) OMunity: create, concept, commit, consistent, collaboration, connect, and contribution. If described the foundation of 'vitamin C' as follows: when making something, then the first thing to think about is the concept. Once 


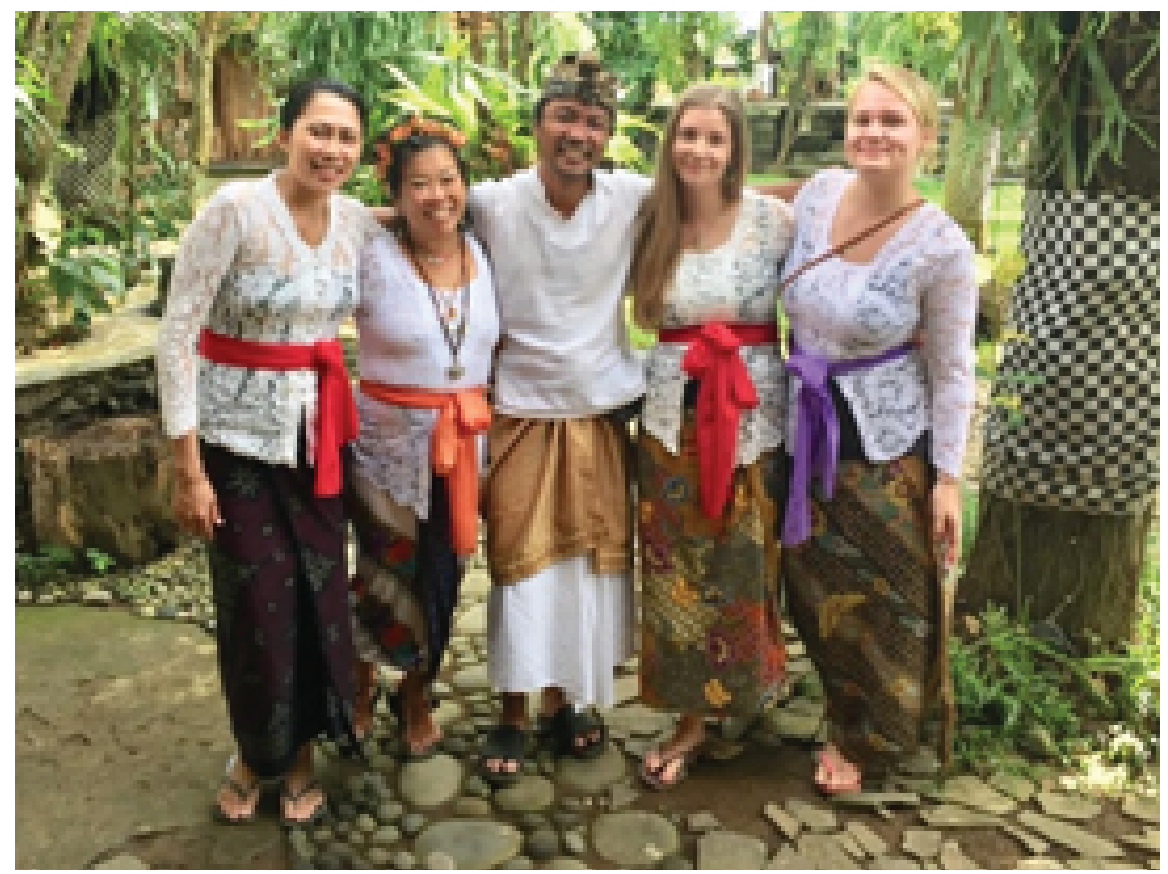

Figure 2: Zanzan (at the center) and the tourists.

the concept is created, then the next thing that needs to be held is a strong commitment to the idea that we build. The strong commitment must be accompanied by consistent action so that the idea built can be sustainable. When these four things are in hand, this is the capital to collaborate on building the village, by establishing connections created from visits to OMunity, to make a real contribution to the development of Sudaji Village towards Spiritual Tourism Village. Consonant removal of $\mathrm{C}$ in the Community to become OMunity not merely because of vitamin $\mathrm{C}$ above, but a long thought process that underlies the development towards spiritual tourism. The word OMunity is divided into Om and Unity. Om is the highest mantra in Hinduism; all the realities that exist in all realms; the symbol of life, Om is Brahman, the creator. So the essence of OMunity is the means of physical and spiritual union towards Brahman, the highest spiritual spirit.

\subsection{A form of ecologically-based spiritual tourism development}

OMunity Bali wants to show that environmental sustainability and community development comes entirely in the hands of the community itself, certainly based on the philosophy of Tri Hita Karana. The harmony and balance between the people of Sudaji, nature, and God. OMunity offers experience; tourists who come from abroad are invited to feel firsthand how to live every day and interact with the community of Sudaji village. The people who are members of OMunity will provide one renovated room for homestay. The community and children are also involved in various educational programs, local 
community empowerment, and environmental hygiene. OM Stay which is considered as the heart of OMunity Bali is built to the maximum extent without damaging nature. Existing trees are not cut down and treated very well. The building is entirely using environmentally friendly materials built of wood and bamboo, built among existing trees. OMunity Bali provides eco-friendly tourist accommodation. The guest bed consists of traditional bamboo huts that are inspired by the shape of a local cow house. Tourists can feel the sensation of its bamboo hut. The rooms are about 24 square meters and feature a bedroom with king-size bed, terrace, and bathroom with washbasin, toilet, toiletries and shower with hot and cold water. This room is also equipped with air conditioning, writing desk, free coffee/tea maker and mineral water. The TV is not provided, and the wifi area is limited so that the tourists focus on spending quality time with their loved ones while enjoying nature. A kind of gadget detox that urban people desperately need today.

In front of the bamboo hut there is a swimming pool designed to resemble the symbol of Lingga Yoni in Hinduism. Lingga Yoni Pond is used as a therapeutic health tool, where after meditation in wantilan adjacent to Lingga Yoni pond, tourists are invited to soak while meditating in the pond. Adjacent to the Lingga Yoni pond there is wantilan. Wantilan is a meditation place built of bamboo is done entirely by the surrounding community, with octagonal shaped. The octagon symbolizes the Dewata Nawa Sanga. Dewata Nawa Sanga is the nine gods or manifestations of Ida Sang Hyang Widhi Wasa who guard or control the nine directions of the wind. There are many activities offered by OMunity as ecologically-based spiritual tourism, including Yoga, Meditation, Healing Journey (Cleansing and Purification), Astrology reading, learn to make Balinese herbal medicine, Balinese cooking class, join traditional ceremony (seasonal), trekking to the community compound, trekking to the nature, traditional Sudaji massage, making offers, and traditional art \& amp; craft. Almost all lead to spiritual with the media of nature.

\subsection{Tri Hita Karana as OMunity Bali strategy in development of Sudaji village as ecologically-based spiritual tourism village}

Tri hita karana has meaning "three causes of prosperity" (tri means three; hita means prosperous, and karana means cause), consisting of parahyangan (spiritual environment), pawongan (social environment) and palemahan (natural environment). These three elements (parahyangan, pawongan, and palemahan) constitute an inseparable unity. The harmonious and balanced relationship between the three elements is thought to be able to bring useful benefit for the spiritual and material prosperity of the people. 
On the contrary, unbalanced relationship or relationship focusing on certain aspect is thought to be able to threaten human life prosperity. The concept of tri hita karana contains the notion of human adaptation pattern to their environment. Every human in the world in the effort to maintain his/her life always interact with his/her environment. Such environment includes the spiritual, social and natural environment. In this adaptation, human has a set of knowledge models which are used selectively to consider the environment. The tri hita karana is a knowledge model teaching humans to maintain harmonious relationship and adaptive to environments in the various dimension of space and time. It contains universal values for the sake human life and universe prosperity.

\subsubsection{Parahyangan aspect}

Parahyangan aspect is an expression of the human relationship with his spiritual environment as well as a reflection of human essence as homo religion, namely as a human having a conviction on supreme power or supernatural power. As one of the effort to reach life prosperity, human always tries to maintain a harmonious interaction with the spiritual environment. Interaction process between human and the spiritual environment has produced a various form of the religious system. The existence of religious system has been realized as an important thing for the spiritual needs of human being since life which only runs after physical prosperity without being balanced by spiritual prosperity will throw human being to the darkness.

This parahyangan aspect of OMunity is reflected from the significance and understanding of the essence of OMunity as a means of physical and spiritual union towards Brahman, the highest spiritual level. This naming also directs towards where OMunity implements its spiritual side. The buildings contained in OM Stay have their philosophy. The buildings are not built in the same phase, but gradually following a master plan that has been thought through. The first building that was created is two traditional bamboo huts that are inspired by the form of a local cow house. The selection of the cow house is linked to the cow philosophy as a sacred animal in Hindu mythology. These two bamboo huts are built simultaneously along with the concepts of Purusa and Pradhana, men and women, soul and body; meeting two different things that gave birth to life.

In front of the bamboo hut there is a swimming pool designed to resemble the symbol of Lingga Yoni in Hinduism. Lingga Yoni is a means of worshiping God as a manifestation of Shiva in Hinduism. The Lingga Yoni Swimming Pool is built very naturally. The water is very cool because it is channeled directly from the surrounding mountains. Lingga Yoni Pond is used as a therapeutic health tool, where after meditation in Wantilan adjacent 

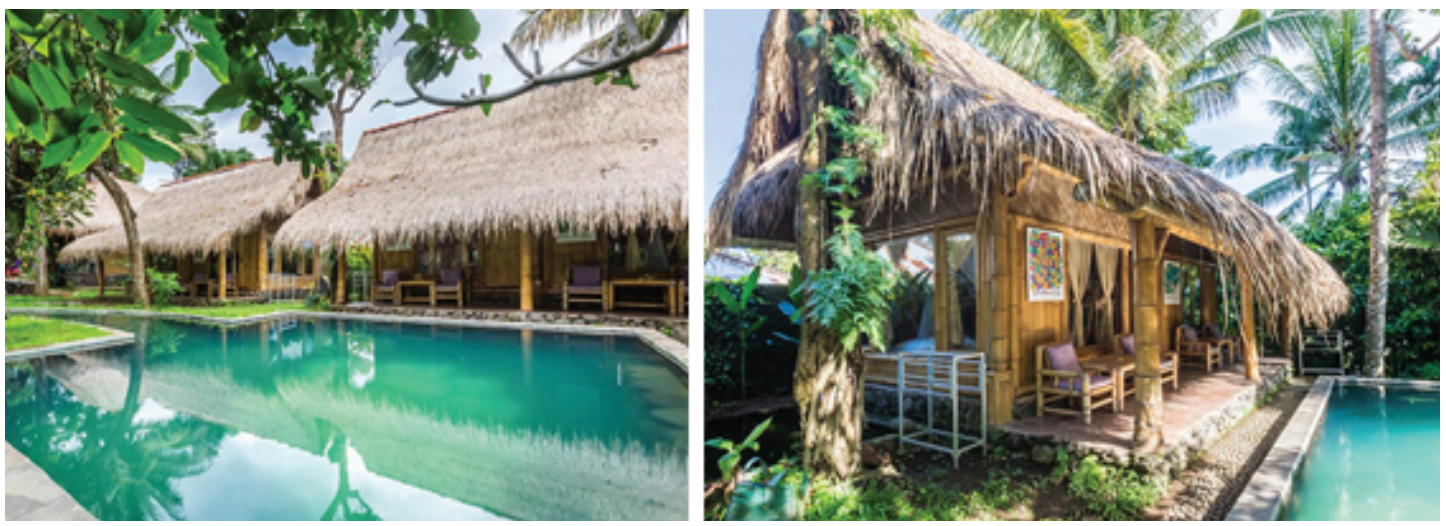

Figure 3: Two bamboo huts inspire from local cow house.

to Lingga Yoni pond tourists are invited to soak while meditating in the pond. Lingga Yoni pond serves as a means of purifying themselves (purify) before attending yoga or meditation activities. Adjacent to the Lingga Yoni pond is wantilan. Wantilan is a meditation place built from bamboo in octagonal shape. The octagon symbolizes the Dewata Nawa Sanga. Dewata Nawa Sanga is the nine gods or manifestations of Ida Sang Hyang Widhi Wasa who guard or control the Nine directions of the wind. Energy from all directions is believed to converge there as a result of meditation and yoga. The dominance of white cloth on the wantilan is used as a decorative element that symbolizes the ninth-color blend of colors in the concept of Dewata Nawa Sanga.

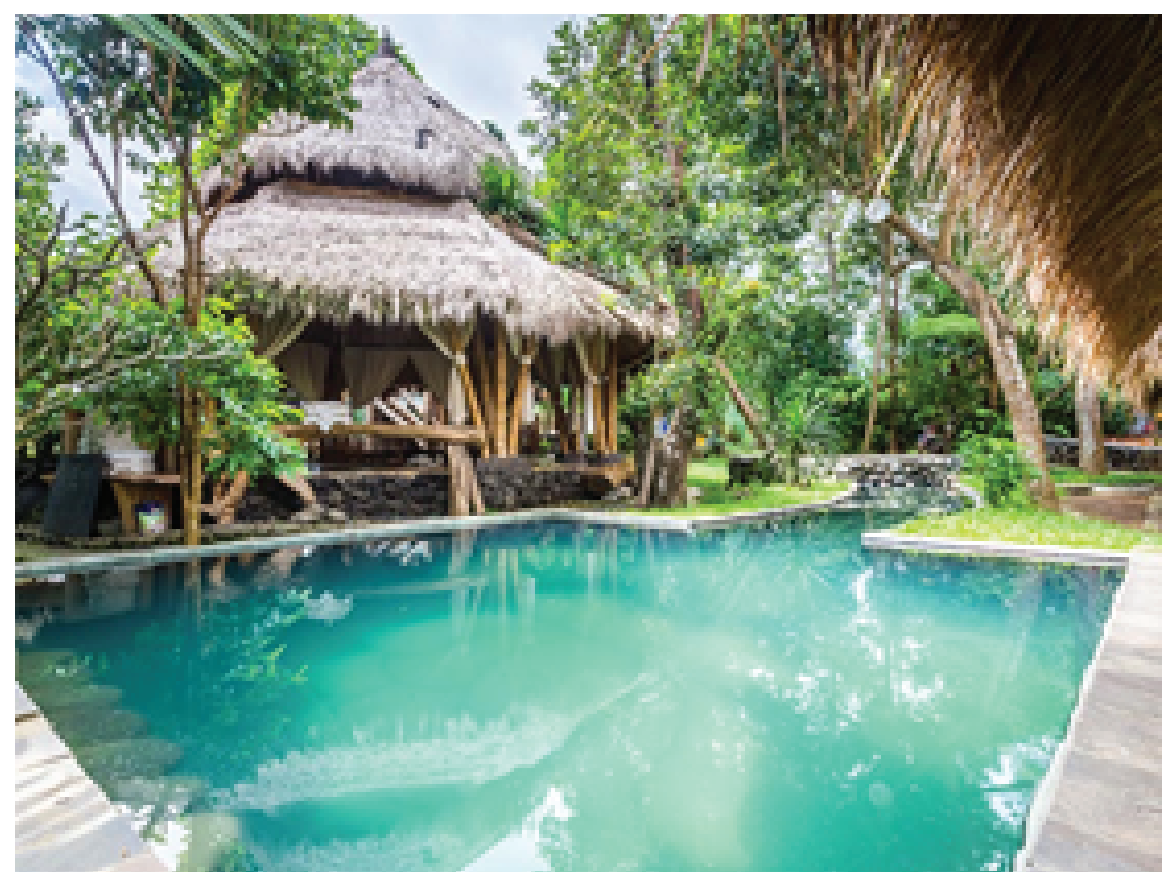

Figure 4: Lingga Yoni pool.

Spiritual activity developed related aspects of this Parahyangan are a healing journey that includes a joint prayer between tourists and residents and then proceed with 


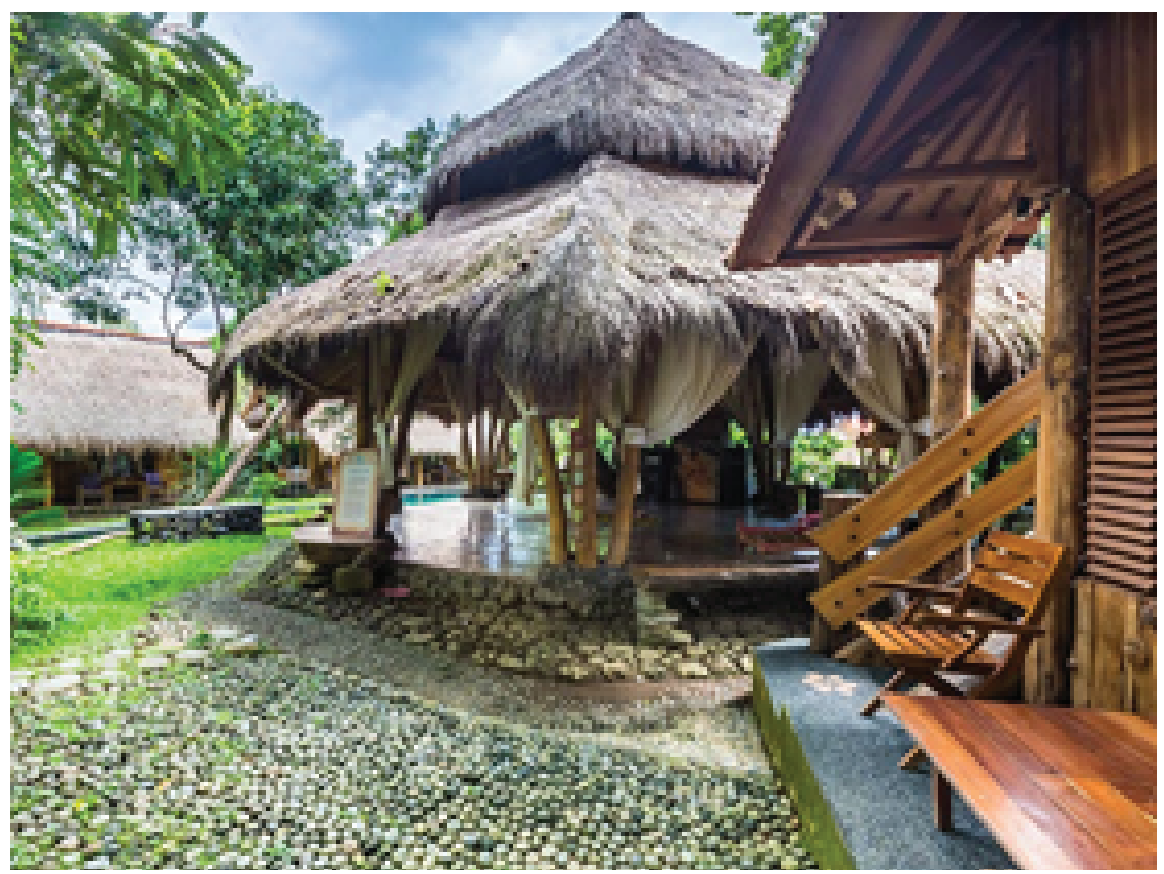

Figure 5: Wantilan.

melukat or cleansing yourself to seven holy springs in the area of waterfall Sekumpul. In everyday life, this aspect of parahyangan is reflected in a common meal activity that is always preceded by common prayer, using OM mantra to give positive energy to food while conveying gratitude to God. Simple activities that are rarely found in tourist accommodations in general. Also, tourists are allowed to learn how to make offerings as a form of creative meditation as well as art therapy.

\subsubsection{Pawongan aspect}

Pawongan aspect is an expression of the human relationship with a similar creature as well as a reflection of human essence as a social creature. It is impossible for a human being to live alone. However, he/she always interact with other human being and become part of their social system. To attaint of a prosperous life, one human being must always maintain a harmonious relationship with another human being. In the effort, the social institution is necessary to manage and guarantee the existence of harmonious relationship among human being. Pawongan aspect reflects a high appreciation of human values, human right, and peace among human being. OMunity offers experience; tourists who come from abroad are invited to feel firsthand how to live every day and interact with the community of Sudaji village. The people who are members of OMunity will provide one renovated room for homestay. The community and children are also involved in various educational programs, local community empowerment, and 
environmental hygiene. At any time if there happens to be a traditional ceremony held by the people of the village of Sudaji, tourists are invited to be part of the community, feel their own manyama-braya experience, the real implementation of pawongan aspect in Balinese Hindu society. Tourists are welcome to join medelokan (visiting a host who has a traditional ceremony), meaban-aban (bringing rice, coffee, sugar to the host), nguopin (preparing phase of ceremony), to mebat (cooking activities with Balinese food for ceremonial purposes) and megibung (eating activities together in one container). This series of indigenous activities as part living culture that should be preserved.

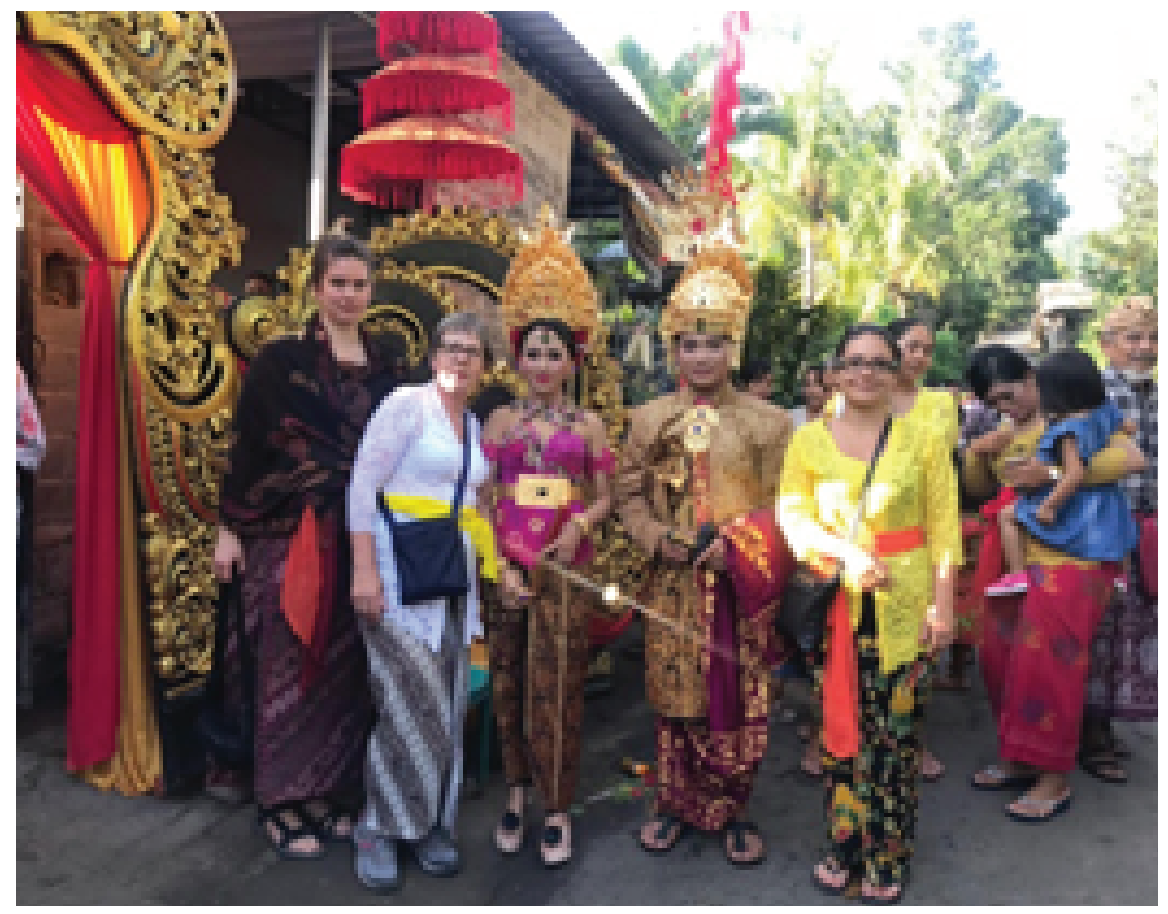

Figure 6: The tourists join medelokan to Balinese Wedding.

The collaboration built between OMunity Bali and Desa Pakraman takes place in harmony among the spiritual activities of praying together between the villagers and the tourists who come to Sudaji which is centered in Pura Maspahit, tracking activity to Sekumpul waterfall, or climbing Madia Hill and the peak of Sudaji Village. Other activities involving the Sudaji and OMunity Bali villagers are devotional work and picking up plastic waste on specific days such as August 17 (celebrating Independence Day and others). The activity of collecting plastic waste involves village administrators, both traditional and customary villages, communities, and even school-age children with the aim that they all learn about the need to keep the environment clean of waste, especially the hard-to-decompose plastic waste. The community is also actively invited to meditate and given education about the need to maintain the environment, so it is expected to bring changes to the behavior of people who still like to dispose of garbage in 


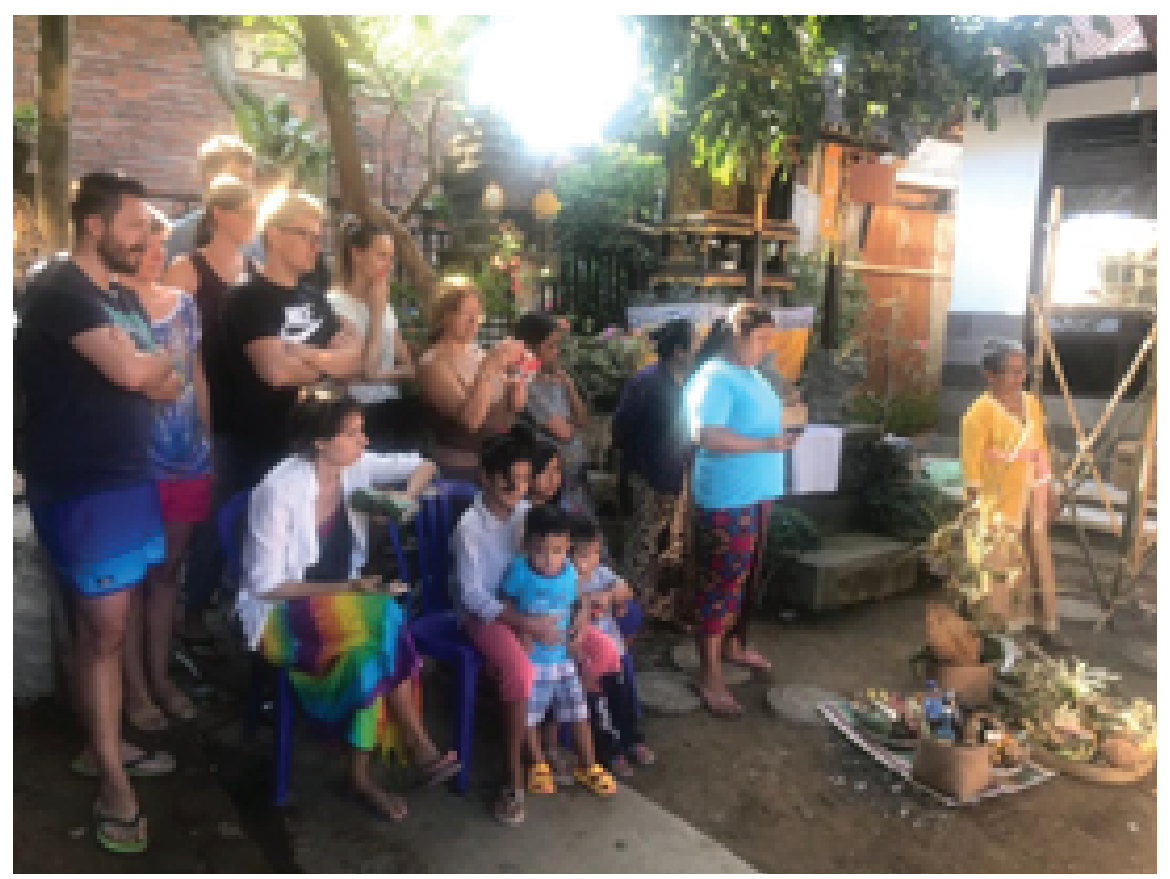

Figure 7: One of manyama-braya experience (visiting the Balinese traditional ceremony).
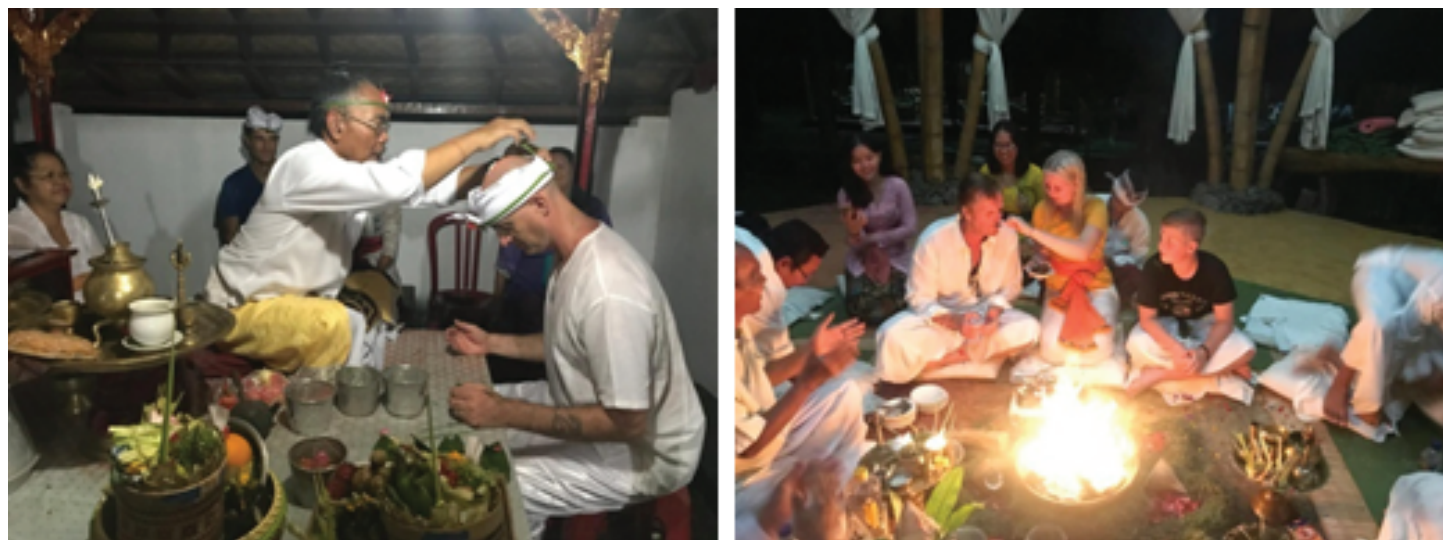

Figure 8: The tourists join Hindu's ritual.

any place. Children from Sudaji Village are also given yoga training and free English courses. Children are the greatest asset in change. Change can only be obtained from a long process, and OMunity Bali starts from simple ways. Children are taught about the need to protect the environment through education, teach them sensitivity to the environment and society through yoga and meditation, and be invited to broaden their horizons by teaching English and allowing children to practice by hanging out with the tourists.

Another form of cooperation provided by OMunity with Desa Pakraman (Balinese traditional government system) is the use of several rooms of the Sudaji Village community as guest beds or homestay. The community provides one renovated room for the guests of OMunity Bali. There are about 65 residents in ten hamlets providing 
one room for OMunity Bali. For residents who provide rooms for OMunity Bali greatly benefit from renting rooms. Community involvement in providing accommodation for tourists visiting Sudaji Village is a positive thing to increase the income of Sudaji Village community. Besides being particularly useful for residents who rent out their rooms, the presence of OMunity Bali is also felt by Desa Pakraman in general, as every guest who comes to Sudaji village is given a donation. The money is put into Desa Pakraman cash which will be used for the development of Sudaji Village. In addition to providing tourist accommodation, OMunity also empowers people to use their own land in their homes as organic gardens that supply food at OM Stay. OMunity buys community garden produce which is certainly healthier and fresh. Cooked directly after the supply to OMunity, and immediately served to tourists. In Hindu belief the food served after being picked is a food that is satwika, because all the substances contained still intact. The menu provided is a homemade vegetarian menu which rich in fiber and vitamins so that indirectly supports detoxify the toxins in the body, in addition to mind and soul healing is detoxified through yoga and meditation.

\subsubsection{Palemahan aspect}

Palemahan aspect is an expression of human relationship with natural environment. To attaint prosperity, human being always try to maintain harmonious interaction with the natural environment. Human arrogance in the form of excessive natural resources exploitation without considering its conservation is a form of inharmonious interaction with the environment. Sooner or later, this will threaten human prosperity.

OM Stay which is considered as the heart of OMunity Bali is built to the maximum extent without damaging the nature. Existing trees are not cut down and treated very well. The building is completely eco-friendly, built of wood and bamboo found around Sudaji Village, using local technique and local labor. There are even buildings built by letting the trees grow in them. The great appreciation of the tree has a positive impact on the existence of Om Stay. OMunity seems to have its own taksu (charisma). The natural atmosphere, the birds chirping, the gurgling of water, the fresh and cool air atmosphere, makes the heart tranquil and comfortable to live.

The appreciation of the tree has its roots in ancient Balinese traditions that impose strict rules on tree utilization. This is seen in the Manawa Swarga lontar, which mentions whoever cut down trees without the permission of the king, is punished by a fine of five thousand keeping. There was even a Pakraman village in ancient times putting in its awig-awig a spiritual sanction if anyone felled trees without the permission of Kelian 


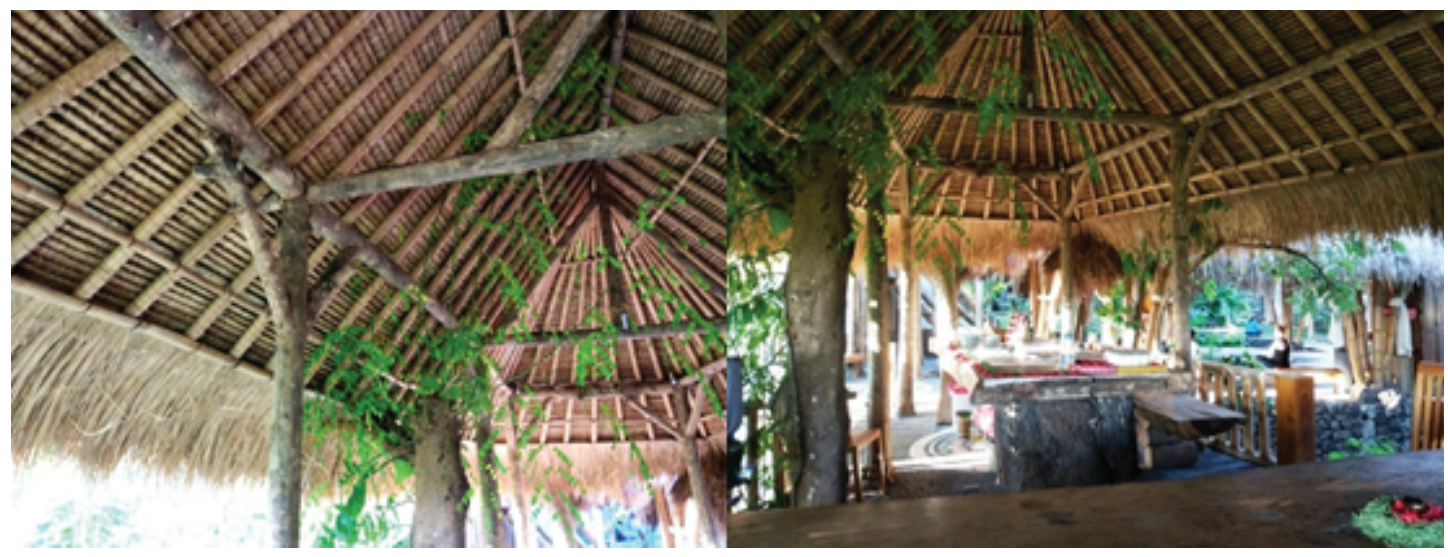

Figure 9: Local technique for dining area construction (tree grow inside).

Desa, his spiritual sanction was in the past or worn a curse for his balding head. Seeing the seriousness of the Balinese society in the past in protecting the environment, it would be questionable if, in the present time, there is no seriousness of the Balinese people to keep their exploited forest resources. Another tourist attraction in the Sudaji Village is a traditional way of farming and using organic fertilizer. The food menu served at OMunity is entirely the result of organic gardening done by the community around OMunity on their homeland.

From the reviews above, it can be seen that there is a common thread between the three principles for sustainable tourism outlined by the WTO (ecological sustainability, socio-cultural survival, and economic sustainability) with the philosophy of Tri Hita Karana; both emphasize harmony between nature and humans, mutual benefit from one another, form a chain of establishment, long-term sustainability. Sustainable environment will certainly provide a longer life for the living things in it, a healthy life for humans. Healthy people will certainly respect each other and all aspects of life, as the socio-cultural development that carries a trace of human dignity. The diversity of socio-cultural backgrounds is the basis for generating unlimited creativity for economic income. The economic value felt by humans will then make humans learn to appreciate nature that has given everything, and so on.

\section{Conclusion}

Several things can be summarized from the development of Ecologically-Based Spiritual Tourism Village by OMunity in Sudaji Village and can be adopted in the development of other sustainable tourism villages in Bali, including: 
1. Omunity uses the concept of 'Village builds' as a pillar of sustainable village tourism development. Village builds means looking inside, exploring the local potential and local wisdom, seeing what the village has and developing it according to the village's ability; minimizing outside influences that are inconsistent with the village character so that the originality of the village is maintained.

2. Local wisdom has the potential to become a unique tourism attraction because each region has a different geographical setting and human efforts, so as produce the distinct character of the village too.

3. Tri Hita Karana should be the basis for the development of tourism villages in Bali. Tri Hita Karana is an ancestral representation that becomes a grip in everyday life of Hindu Balinese and gives taksu for Bali. Tri Hita Karana is a model of knowledge that teaches humans to maintain harmonious and adaptive relationships to the environment in various dimensions of space and time. It contains universal values for the life of man and the prosperity of the universe. Tri Hita Karana has a very wide meaning and interpretative, so that can be developed following desa-kala-patra (place, time, condition) of the tourism village.

\section{References}

[1] Berno, Tracy. Bricker, Kelly. (2001). Sustainable Tourism Development: The Long Road from Theory to Practice. International Journal of Economic Development.

[2] Brent W. Ritchie, Peter Burns and Catherine. (2005). Tourism Research Methods: Integrating Theory with Practice Palmer (eds). Wallingford, UK: CABI Publishing.

[3] Nuryanti, Wiendu. (1993). Concept, Perspective and Challenges, Laporan Konferensi Internasional mengenai Pariwisata Budaya. Yogyakarta: Gadjah Mada University Press. Hal. 2-3.

[4] Putra, I Nyoman Darma dan I Gde Pitana. (2010). Pariwisata Pro-Rakyat Meretas Jalan Mengentaskan Kemiskinan di Indonesia. Jakarta: Kementerian Kebudayaan dan Pariwisata.

[5] Sastrawan, Ketut Bali. (2016). Pengembangan Wisata Spiritual Berbasis Ekologi: Studi Etnografi Omunity Bali di Desa Sudaji, Kecamatan Sawan, Kabupaten Buleleng. Denpasar: Vidya Samhita.

[6] Sendra, I Made. (2011). The Tri Hita Karana Philosophy As A Model Of Rural Tourism Development In Bali. Analisis Pariwisata Vol 1 No 1. Fakultas Pariwisata Universitas Udayana. 
[7] Simanungkalit, Victoria, et al. (2017). Buku Panduan Pengembangan Desa Wisata Hijau. Jakarta: Kementrian Koperasi dan UKM Republik Indonesia.

[8] Trimarianto, Ciptadi. Dudek, Steven. (2011). The Future of Sustainable Development in Bali. Forum E-journal 10. Newcastle University.

[9] Wikantiyoso, Respati. Tutuko, Pindo. (2009). Kearifan Lokal dalam Perencanaan dan Perancangan Kota untuk Mewujudkan Arsitektur Kota yang Berkelanjutan. Malang: Group Konservasi Arsitektur \& Kota.

[10] Nelson, J.G., et al. (1993). Tourism and Sustainable Development:Monitoring, Planning, Managing. Waterloo: Dept. of Geography. Univ. of Waterloo. 